\title{
AN ELECTROPHORETIC STUDY OF THE PROTEIN COMPONENTS IN CEREBROSPINAL FLUID AND THEIR RELATION- SHIP TO THE SERUM PROTEINS ${ }^{1}$
}

\author{
By ELVIN A. KABAT, DAN H. MOORE AND HAROLD LANDOW 2 \\ (From the Departments of Neurology and Anatomy and the Electrophoresis Laboratory, \\ College of Physicians and Surgeons, Columbia University, and \\ the Neurological Institute, New York)
}

(Received for publication May 2, 1942)

Increases in the total protein content of cerebrospinal fluid frequently occur in diseases of the nervous system, and the determination of total protein content is one of the most useful diagnostic laboratory procedures to the neurologist (1). The origin of the cerebrospinal fluid protein is usually considered to be the blood plasma and the increases in total protein content in meningitis are believed due to transudation of serum through the walls of inflamed vessels (1). In other conditions, such as polyneuritis, the reason for the elevated protein content is not clear (1). There are few data available regarding the composition of the cerebrospinal fluid proteins, chiefly because the small amounts of protein present make chemical studies difficult. Freund (2) has shown that the titre of antibody in the spinal fluid of passively immunized rabbits is about $1 / 300$ that of the serum, which is of the same order as the ratio of the total protein of spinal fluid to that of serum. By the use of the Tiselius electrophoresis technic (3), the authors were able to demonstrate that the electrophoretic patterns of concentrated cerebrospinal fluids were similar to those of serum (4). The present report covers a more extensive study of the effect of variations in the serum proteins on the composition of the cerebrospinal fluid proteins, and of the changes in the proportions of the cerebrospinal fluid proteins in various neurological conditions. The fraction of cerebrospinal fluid associated with abnormal colloidal gold activity is identified, and the inhibiting effects of the albumin fraction on the colloidal gold reaction are considered.

\section{EXPERIMENTAL}

Cerebrospinal fluids were obtained from patients on whom encephalography or ventriculography was per-

\footnotetext{
1 Aided in part by a grant from the William J. Matheson Commission.

2 Dr. Landow died on March 27, 1942.
}

formed. Volumes of cerebrospinal fluid as large as 80 ml. were obtained in this manner. Samples were taken for the colloidal gold test and for determination of the total protein content. The rest of the fluid was then placed in a cellophane dialyzing membrane with a one hole rubber stopper at one end and a solid rubber stopper at the other. The membrane was connected by rubber and glass tubing to a small tank of nitrogen, and a gas pressure of 5 pounds per sq. inch (about $250 \mathrm{~mm}$. $\mathrm{Hg}$ ) was constantly maintained on the inside of the membrane. The membrane was immersed in saline so that it was completely covered and the entire apparatus was kept in the icebox at about $5^{\circ} \mathrm{C}$. Under these conditions it was found possible to concentrate the cerebrospinal fluids from $70 \mathrm{ml}$. to about $2 \mathrm{ml}$. in about 2 to 3 days. Several fluids may be concentrated simultaneously by the use of a "Y" tube connecting to the nitrogen tank. It is necessary to test the membranes by applying 5 pounds pressure for several hours before adding the spinal fluid to avoid loss of the specimen in weak membranes or through the connections. After the fluid is concentrated to the desired volume, it is redialyzed against a solution containing 0.15 $\mathrm{M} \mathrm{NaCl}+0.02 \mathrm{M}$ phosphate buffer at $\mathrm{pH} 7.4$ and is studied in the Tiselius electrophoresis apparatus, using a microcell of $2 \mathrm{ml}$. capacity.

Serum samples were diluted about $1: 4$ and dialyzed against the same saline phosphate buffer used for the spinal fluids.

The Tiselius electrophoresis cell (3) consists of a U-tube having a rectangular cross-section, the end walls of which have high optical quality so that light refraction caused by concentration gradients in the solution can be detected accurately. The concentrated cerebrospinal fluid is placed in the bottom half of the U-tube underneath a buffer against which it has been previously dialyzed until its conductivity and $\mathrm{pH}$ have assumed approximately the same value as that of the buffer. To facilitate filling and recovery of material after separation, the electrophoresis cell (U-tube) is divided into sections with sliding flange plates, so that each section may be sealed off from the rest of the system. The tops of the U-tube connect to large buffer vessels containing electrodes. The whole is placed in a water bath thermostatically maintained at a low temperature $\left(1.5^{\circ} \mathrm{C}\right.$. in our work). A boundary is formed by aligning the section containing the protein solution with the rest of the cell. A regulated voltage applied to the electrodes causes a constant current to flow. Convectional disturbances due to heat are mini- 

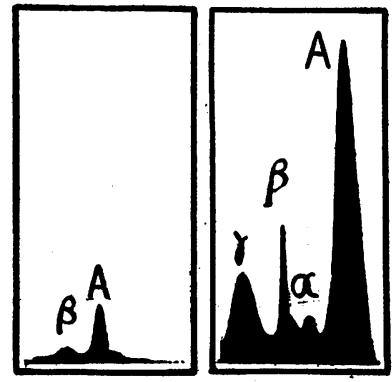

A

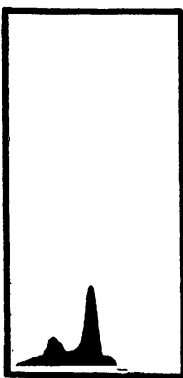

G

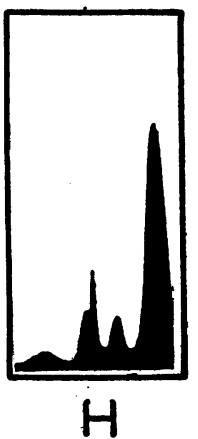

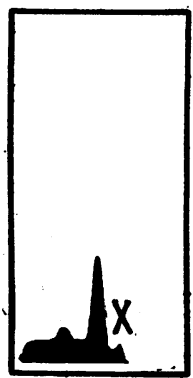

C

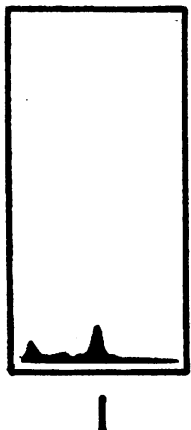

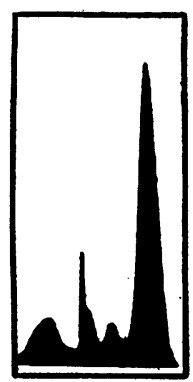

D

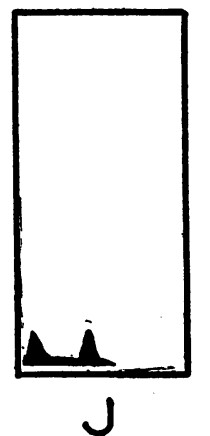

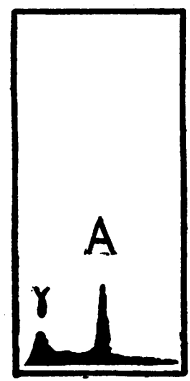

E
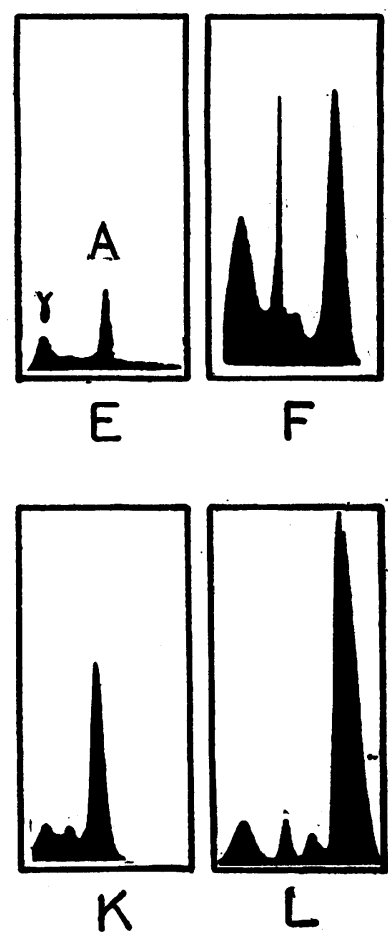

Fig. 1. Electrophoretic Patterns

$\begin{aligned} & \text { Case number } 661981 \text {-Idiopathic grand mal (normal) } \\ & 647635 \text {-Anxiety state (normal) } \\ & \text { 652282-Lymphopathia venereum } \\ & 661095 \text {-Multiple myeloma } \\ & \text { WH 138-Multiple sclerosis } \\ & \text { 655751-Neurosyphilis } \\ & \text { 635202-Diabetic neuritis } \\ & \text { 652371-Left frontal cystic astrocytoma }\end{aligned}$
A Spinal fluid
C Spinal fluid
E Spinal fluid
G Spinal fluid
I Spinal fluid
J Spinal fluid
$\mathrm{K}$ Spinal fluid
L Cyst fluid

B Serum

D Serum

F Serum

$\mathrm{H}$ Serum

mized by maintaining the mean temperature (temperature is highest at center and lowest at walls of cells) of the solution at the point where the change of density with temperature is least (temperature of maximum density). Convection limits the wattage which may be dissipated in the cell.

The current produces an electrical field throughout the cell. If the cell has a uniform cross-sectional area, $A c^{2}$, the field $E$ equals $I / K A$ where $I$ is the current in amperes and $K$ is the specific conductivity of the solution in reciprocal ohms. This electrical field causes the different protein components of the solution to migrate at a rate proportional to the statistical surface charge per unit area of the particles or molecules, and in a direction determined by the sign of this charge. This rate of migration, in $\mathrm{cm}$. per second per unit field in volts per $\mathrm{cm}$., is designated as the mobility of the component.

Bending of light rays caused by concentration gradients at the boundaries of each component may be detected by various optical methods; in this study, the Toepler "Schlieren" method, as modified by Longsworth (5), was used. With this method each electrophoretically distinct protein component gives a symmetrical curve, the area of which is the total refractive index change and is proportional to the concentration of the protein component. By integrating the area for each component in the patterns (Figure 1), the relative concentrations may be obtained, assuming that the specific index of refraction of all components is the same.

After the migration is complete, samples of pure individual components may be removed from the U-tube and tested for colloidal gold activity, etc.

The total protein content of the cerebrospinal fluid was determined turbidimetrically by precipitation with sulfosalicylic acid. The concentration of any electrophoretic component in the original spinal fluid was obtained by multiplying the total protein content of the fluid by the percentage composition of that component as calculated from the electrophoretic pattern.

The colloidal gold tests were carried out in the usual manner, by addition of $2.5 \mathrm{ml}$. colloidal gold solution to $0.5 \mathrm{ml}$. of spinal fluid dilutions of $1: 10,1: 20,1: 40 \ldots$ $1: 5120$. The tubes were allowed to stand at room temperature and read after 24 hours. The color changes 


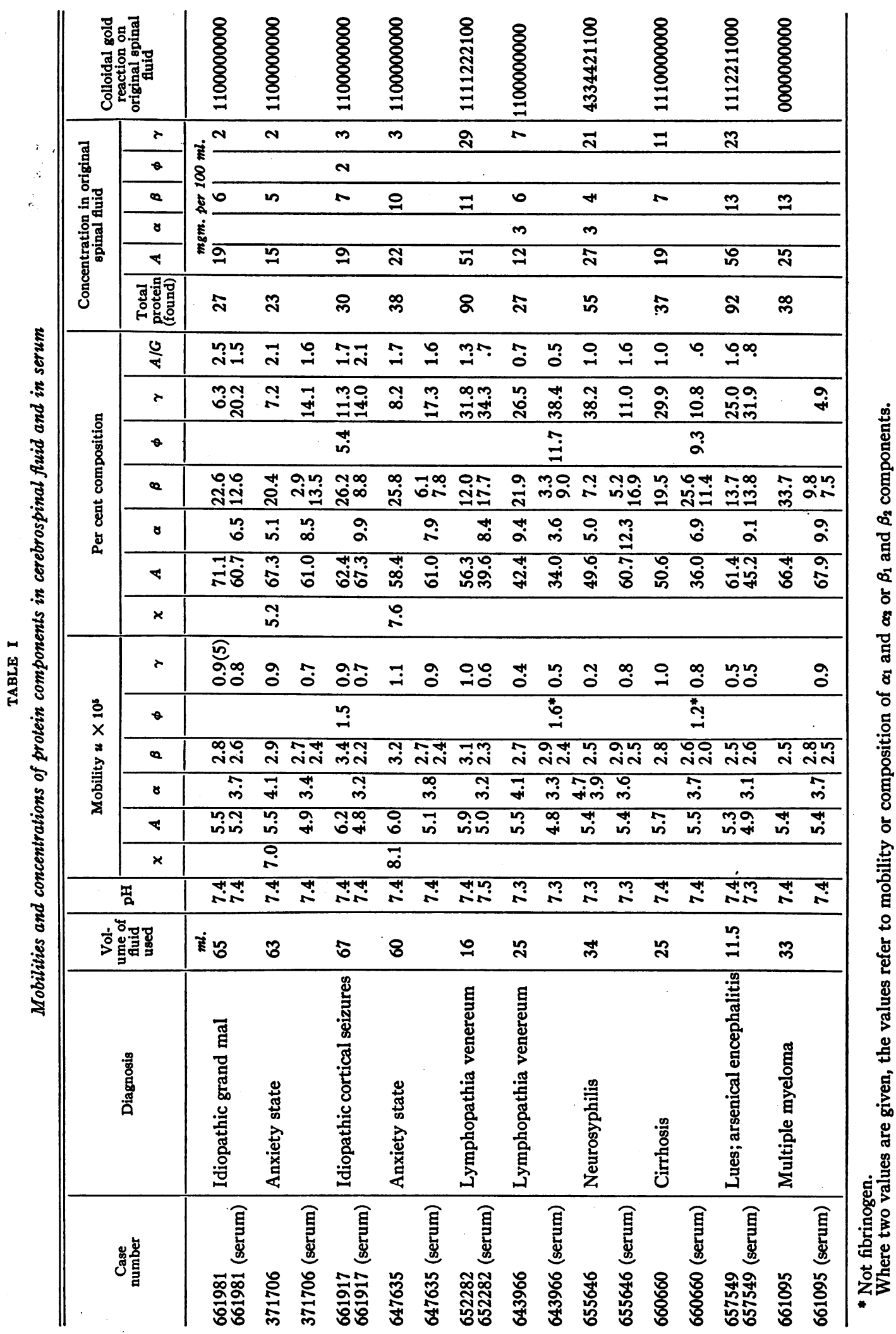


were expressed by numbers as follows: 0-no change, 1-reddish blue, 2-lilac, 3-blue, 4-pale blue, 5-colorless. The results are given by the values recorded for each tube, beginning with the highest concentration of spinal fluid, as in the usual procedure.

\section{RESULTS}

Table I shows the mobilities and concentrations of the protein components in cerebrospinal fluid and serum from a number of individuals. The first 4 cases listed showed relatively normal levels of total spinal fluid protein and may be taken to represent the composition of normal cerebrospinal fluids. It can be seen from the table that the mobilities of the components in the cerebrospinal fluid correspond closely to those of the blood, except that alpha globulin and fibrinogen are frequently absent. In addition, some spinal fluids contained a small amount of a component designated as " $x$," with a mobility faster than that of the albumin (Figure 1, $\mathrm{A}$ and $\mathrm{C}$ ). The percentage composition and the amount of each fraction in mgm. per $100 \mathrm{ml}$. are also included. The effect of changes in the amounts of the serum protein components on the composition of the spinal fluid proteins is illustrated in the cases of lymphogranuloma venereum (Figure $1, \mathrm{E}$ and $\mathrm{F}$ ) and cirrhosis (Table I). It will be noted that increases in the gamma globulin of the serum are accompanied by an elevated gamma globulin in the spinal fluid and a lower $A / G$ ratio, but that the spinal fluid changes are not as marked as are those of the blood. Similarly, in the case of multiple myeloma, an increased beta globulin in the serum was accompanied by an increase in beta globulin in the spinal fluid (Figure $1, \mathrm{G}$ and $\mathrm{H}$ ). In the case of organic disease of the nervous system, such as neurosyphilis (case 655646), which showed colloidal gold changes in the spinal fluid, the increase in gamma globulin was not a reflection of the blood picture.

The results obtained by electrophoretic analysis of a series of normal and pathological spinal fluids are shown in Table II. The first 5 fluids may be considered as normal. As in Table I, it may be noted that alpha globulin and fibrinogen are not usually seen in normal cerebrospinal fluids, but appear in those with elevated total protein content. The data obtained with fluids from 5 cases of multiple sclerosis showed no marked change from the normal except in one case which showed colloidal gold changes (WH138), and which was found to have a high gamma globulin (Figure 2) and an $\mathrm{A} / \mathrm{G}$ ratio of 0.8 . The serum of this case also showed a high globulin. Three of the 4 cases of neurosyphilis in Table II, as well as the case in Table I, showed a high gamma globulin (Figure $1, \mathrm{~J}$ ) and colloidal gold changes were observed in those cases with the highest gamma globulins. In these cases, the $A / G$ ratio of the spinal fluid was also very low.

Four cases of brain tumors showed elevated total protein and it was found that the bulk of this increase was due to albumin, with slight increases in the amount of the other components. A fifth case showed a relatively normal cerebrospinal fluid pattern and the diagnosis of brain tumor was not made from the cerebrospinal fluid. The last 3 values in the table were obtained by using the fluids from cystic tumors. These fluids had protein contents of 5,4 , and 6 per cent respectively and were diluted with buffer to about 2 per cent. These cyst fluids also showed very high albumin peaks and high $\mathrm{A} / \mathrm{G}$ ratios (Figure $1, \mathrm{~L}$ ).

The data obtained with 5 cases of peripheral neuritis, with a high total protein, also showed that the bulk of this increase was due to albumin, with some increase in the other protein components (Figure 1, K). In all but one of these cases, alpha globulin was present. In one case complicated by syphilis, an elevated gamma globulin was also found.

A case of meningitis of unknown etiology showed a normal $A / G$ ratio with a very high total protein content and an increase in all components.

The relationship of the colloidal gold activity to the composition of cerebrospinal fluid is shown in Table III. Pure albumin and gamma globulin fractions were obtained from the electrophoresis cell and tested for colloidal gold activity. The middle fraction was a slightly changed spinal fluid due to the migration of the various components. It can be seen that in no case was activity found in the albumin fraction, and that the separated gamma globulin had a higher activity than either the original spinal fluid or the middle fraction. This indicates that the colloidal gold activity migrated with the gamma globulin fraction, and that 


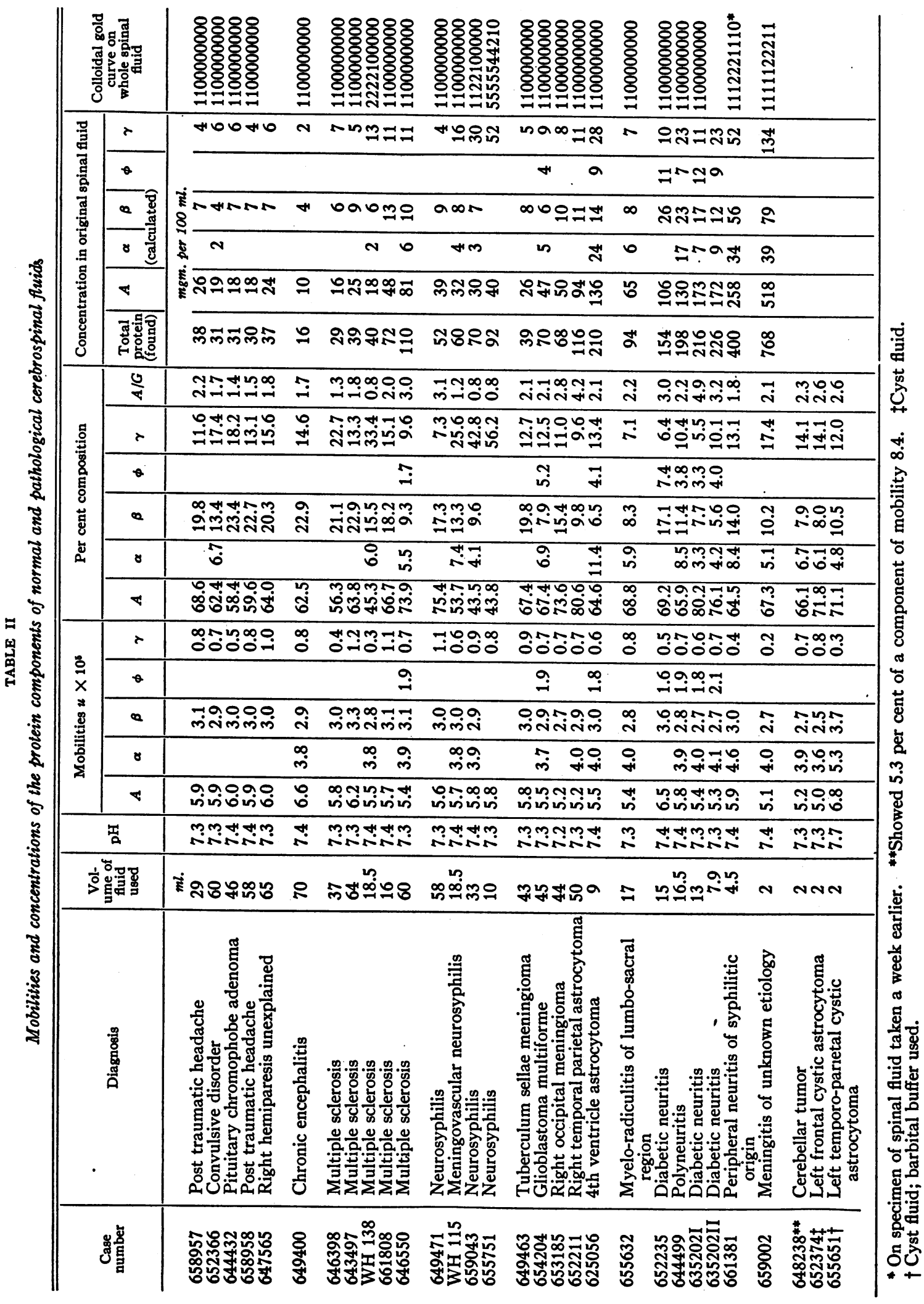


TABLE III

Colloidal gold curves on electrophoretic fractions of concentrated spinal fluids

\begin{tabular}{|c|c|c|c|c|c|}
\hline \multirow{2}{*}{$\begin{array}{c}\text { Case } \\
\text { number }\end{array}$} & \multirow[b]{2}{*}{ Diagnosis } & \multicolumn{4}{|c|}{ Colloidal gold curves } \\
\hline & & $\begin{array}{l}\text { Original un- } \\
\text { concentrated } \\
\text { spinal fluid }\end{array}$ & Albumin & Middle & Gamma \\
\hline $\begin{array}{l}661981 \\
661917 \\
647635 \\
658958 \\
635202 \\
660660 \\
661808 \\
\text { WH } 138 \\
655751 \\
659043 \\
657549 \\
659002\end{array}$ & $\begin{array}{l}\text { Idiopathic grand mal } \\
\text { Idiopathic cortical seizures } \\
\text { Anxiety state } \\
\text { Post traumatic headache } \\
\text { Polyneuritis } \\
\text { Cirrhosis } \\
\text { Multiple sclerosis } \\
\text { Multiple sclerosis } \\
\text { Neurosyphilis } \\
\text { Neurosyphilis } \\
\text { Lues; arsenical encephalitis } \\
\text { Neurosyphilis }\end{array}$ & $\begin{array}{l}1100000000 \\
1100000000 \\
1100000000 \\
1100000000 \\
1100000000 \\
1110000000 \\
1100000000 \\
2222100000 \\
5555544210 \\
1122100000 \\
1112211000 \\
1111122211\end{array}$ & $\begin{array}{l}0000000000 \\
0000000000 \\
0000000000 \\
0000000000 \\
0000000000 \\
0000000000 \\
0000000000 \\
0000000000 \\
0000000000 \\
0000000000 \\
0000000000 \\
0000000000\end{array}$ & $\begin{array}{l}0000000000 \\
0000000000 \\
\\
0000000000 \\
0000000000 \\
1111222110 \\
2112221100 \\
3322221100 \\
5554332110 \\
3332233321 \\
111122210 \\
1112221000\end{array}$ & $\begin{array}{l}1112210000 \\
3321000000 \\
0000000000^{*} \\
0000000000 \\
1112332210 \\
1243210000 \\
\mathbf{5 4 3 2 1 0 0 0 0 0} \\
\mathbf{5 5 5 3 3 2 1 0 0 0} \\
\mathbf{5 5 5 5 4 3 2 1 0 0} \\
\mathbf{5 5 5 4 4 3 1 1 0 0} \\
\mathbf{5 5 5 5 4 3 2 1 0 0} \\
\mathbf{5 5 5 4 3 2 1 0 0 0}\end{array}$ \\
\hline
\end{tabular}

* Whole globulin.

the albumin had an inhibiting effect on the colloidal gold reaction. In gamma globulin samples obtained from sera showing colloidal gold changes, it was possible completely to abolish the colloidal gold reaction by adding albumin. Details will be published in a separate communication.

\section{DISCUSSION}

The observation that changes in the electrophoretic patterns of the spinal fluid are influenced by changes in the composition of the serum proteins strongly indicates that much of the spinal fluid protein is derived from the blood. The order of magnitudes of the ratios of spinal fluid gamma globulin to serum gamma globulin are in agreement with the average of $1: 300$, found by Freund, for the distribution of antityphoid agglutinins between the spinal fluid and serum of rabbits. This is not surprising as human antipneumococcus antibody and rabbit antibodies to several types of antigens were found to have the same molecular weights as their respective gamma globulins (6), and hence would be distributed on both sides of the hemato-encephalic barrier to the same extent.

The data obtained in neurosyphilis (case 655646), however, suggest that not all of the spinal fluid protein is derived from the blood. In this case, the $A / G$ ratio of the spinal fluid was much lower than that of the blood and the percentage of gamma globulin was much higher than that in the serum. This spinal fluid also showed colloidal gold changes which are associated with increases in the gamma globulin. The data would suggest that some formation of gamma globulin could take place within the tissues of the central nervous system and be poured into cerebrospinal fluid, since it is difficult to imagine an altered permeability of the hemato-encephalic barrier which could produce an increase in gamma globulin without producing the same or an even greater increase in the smaller albumin molecule. The formation of some gamma globulin in the central nervous system is in accord with the views of Katzenelbogen (7) that cerebrospinal tissues are capable of producing antibodies, and that the origin of the antibodies in the cerebrospinal fluid is twofold, from the blood and from the cerebrospinal tissues. It also agrees with the views of Sabin (8) who has suggested that antibodies and normal gamma globulin are formed in the cells of the reticulo-endothelial system by a partial shedding of their surface cytoplasm. This hypothesis will explain the electrophoretic data as well as the fact that positive Wasserman reactions may be obtained frequently in spinal fluid, but not in the serum, in cases of neurosyphilis.

\section{SUM MARY}

1. The electrophoretic pattern of cerebrospinal fluid resembles that of serum.

2. Alterations in the composition of the protein components of serum are reflected in the cerebrospinal fluid, but the changes are not as marked. 
In neurosyphilis, however, an increased gamma globulin occurs in cerebrospinal fluid, without similar changes in the blood stream.

3. Colloidal gold activity is associated with the gamma globulin fraction, and albumin has an inhibiting effect on the colloidal gold reaction.

The authors are indebted to Drs. Tracy J. Putnam and Robert F. Loeb for many suggestions and for assistance in obtaining material. The colloidal gold tests were carried out by Miss Ruth Shivitz of the Department of Bacteriology, and Misses Sheila Goldsmith and Helen Sikorski assisted in the electrophoretic experiments.

\section{BIBLIOGRAPHY}

1. Merritt, H. H., and Fremont-Smith, F., Cerebrospinal Fluid. WV. B. Saunders Co., Philadelphia, 1937.
2. Freund, J., Accumulation of antibodies in the central nervous system. J. Exper. Med., 1930, 51, 889.

3. Tiselius, A., A new apparatus for electrophoretic analysis of colloidal mixtures. Tr. Faraday Soc., 1937, 33, 524.

4. Kabat, E. A., Landow, H., and Moore, D. H., Electrophoretic patterns of concentrated cerebrospinal fluid. Proc. Soc. Exper. Biol. and Med., 1942, 49, 260.

5. Longsworth, L. G., A modification of the schlieren method for use in electrophoretic analyses. J. Am. Chem. Soc., 1939, 61, 529.

6. Kabat, E. A., The molecular weight of antibodies. J. Exper. Med., 1939, 69, 103.

7. Katzenelbogen, S., The Cerebrospinal Fluid and its Relation to the Blood. Johns Hopkins Press, Baltimore, 1935.

8. Sabin, F. R., Cellular reactions to a dye-protein with a concept of the mechanism of antibody formation. J. Exper. Med., 1939, 70, 67. 